http://jmscr.igmpublication.org/home/ ISSN (e)-2347-176x ISSN (p) 2455-0450

crossref DOI: https://dx.doi.org/10.18535/jmscr/v7i11.14

Journal Of Medical Science And Clinical Research

\title{
A Pre-Experimental Study Assess the Knowledge on Biomedical Waste Management (BMW) among GNM final year Nursing Students of Selected Colleges at Distt Mandi (H.P)
}

\author{
Authors \\ Minal Panwar ${ }^{1}$, Nisha Kumari ${ }^{2}$ \\ ${ }^{1}$ Assistant Professor, Abhilashi College of Nursing, India, 175008 \\ ${ }^{2}$ Associate Professor, Abhilashi College of Nursing India, 175008
}

\section{Abstract}

Knowledge regarding bio medical waste management plays a vital role in nursing students for their clinical practice.

Aim and Objectives: The study aim to assess the knowledge of bio medical waste management among GNM final year nursing students and to find out the association between knowledge and demographic variables regarding Bio medical waste management.

Methodology: Pre-experimental one group pre-test-post-test design was. A total of 100 students were enrolled into the study by using convenient sampling technique. The structured closed ended questionnaire was used to assess the knowledge

Result: After pre-test majority of nursing students (84\%) had Average knowledge regarding bio medical waste management, Poor knowledge (13\%), good (3\%) and excellent (none). After Post- Test majority of nursing students (57\%) had excellent knowledge regarding bio medical waste management, good knowledge (31\%), Average (12\%) As calculated chi test was use to determine the association between the score levels and selected demographic variables and " $t$ " test value was significant.

\section{Introduction}

"YOU SEE THINGS AND SAY, WHY? BUT I SEE THINGS AND SAY WHY NOT",

Human beings or animals or in the research activities pertaining thereto or in the production or testing of biological and including categories mentioned in Biomedical waste is are any wastes generated during the diagnosis, treatment or immunization of schedule.

In the developing countries, the waste gets dumped in open areas where rag pickers and beggars in value in search of goods, risk their lives by contacting hazardous disease. Many hospitals in the developed countries are recycling or donating the scraps to the developing countries, for instance at least $50 \%$ of the US hospitals send their single use items to the reprocesses who in turn resell them at relatively low prices after sterilizing them.

\section{Need for the Study}

Nursing as a profession is now accountable of staff and students nurses for competence and performance. The nurses spend maximum time with patients in the ward than any other member of the health team, increases their exposure and risk to the hazards present in hospital environment, mainly biomedical waste they need to be well equipped with latest information, skills and practice in managing this waste besides 
reducing hospital acquired infections to protect their own health they are also responsible for preventing risk due to waste to the other members of health team and community at large ${ }^{7}$.

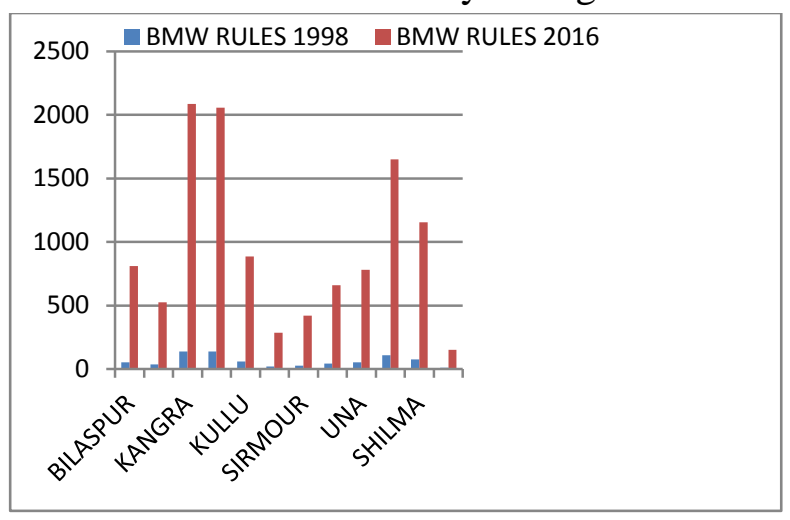

Fig 1: Bar graph showing comparison of number of health care facilities covered under BMW rules $1998-2016$

\section{Statement of Problem}

"A Pre-Experimental Study assess The Knowledge on Biomedical Waste Management (BMW) among GNM Final Year Nursing Students Of Selected Colleges At Distt Mandi (H.P)"

\section{Objectives}

- To assess the knowledge regarding bio medical waste management (BMW) among GNM final year Nursing students at Distt Mandi.(H.P)

- To find out the association between knowledge and selected demographic variables Bio-Medical Waste management.

\section{Hypothesis}

$\mathbf{H}_{\mathbf{1}}$ There will be significant association between knowledge and demographic variables

$\mathbf{H}_{\mathbf{0}}$ There will be not be significant association between knowledge and demographic variables

\section{Assumption}

1) GNM final year Nursing students may have some knowledge regarding BMW

2) Providing booklet will increase the knowledge of nursing students regarding BMW.

\section{Delimitations}

The GNM $3^{\text {rd }}$ year student who are studying in selected nursing colleges and school of Distt Mandi (H.P)

\section{Methodology}

Research approach and design: To assess the knowledge regarding biomedical waste management among G.N.M nursing students a Pre- experimental one group pre test-post test design with Quantitative research approach.

Setting of the study: The study was undertaken Nursing colleges at Distt, Mandi H.P.

Population: The population for the study comprised G.N.M Nursing students of selected nursing colleges.

Samples: Samples of the study were G.N.M. Nursing students of the selected colleges of Distt. Mandi H.P.

Sample Size: Sample size were 100.The samples included 40, 35 and 45 students respectively from each college.

Sampling Technique: In the present study the G.N.M. Nursing students were selected by convenient sampling.

Inclusion Criteria The following inclusion criteria are set to select the samples.

- G.N.M. final year Nursing students

- Students available at the time of data collection

- Those who have consented to participate in the study.

Exclusion Criteria Samples excluded in the present study were students,

- The study excluded the students those who had already participated in the same type of study.

- Those colleges who are not given the permission for data collection.

\section{Description of the Tool}

Section-A: The Performa for sample characteristics was developed together personal data about Nursing Student i.e. age, gender, residence, marital status, religion Education, source of information, college area Clinical area, 
Previous knowledge regarding the Bio medical waste management.

Section-B: Each correct question was awarded a score of "1"and for every incorrect question a score of "0" was given. Thus, total score on structured knowledge questionnaire ranged from 0-30, maximum possible score was " 30 "and minimum score was " 0 ”.

\begin{tabular}{|l|c|c|c|}
\hline S.No. & $\begin{array}{c}\text { Level of } \\
\text { knowledge }\end{array}$ & $\begin{array}{c}\text { Range of } \\
\text { score }\end{array}$ & $\begin{array}{c}\text { Percentage of } \\
\text { score }\end{array}$ \\
\hline 1. & Excellent & $25-30$ & $>83 \%$ \\
\hline 2. & Good & $20-24$ & $66-80 \%$ \\
\hline 3. & Average & $11-19$ & $36-63 \%$ \\
\hline 4. & Poor & $0-10$ & $<33 \%$ \\
\hline
\end{tabular}

\section{Validity of the Tool}

Items were judged by 7 experts for relevance, clarity and appropriateness. Modifications were done in the tool as per expert opinion.

\section{Reliability of the Tool}

Reliability was established by split half method.

The steps adopted for development of information booklet were as follows-

- Review of Literature

- Journals, Books, internet as sources used

- Opinions and suggestions from guide

\section{The contents covered the following areas-}

- Solid waste Management

- Liquid waste management

- Liquid waste management

- Laboratory waste management

- Sharps waste management

\section{Data Collection Procedure}

Formal permission for final data collection of the study was obtained from the concerned authorities of various selected colleges from Distt Mandi (H.P). The study was conducted in April, 2019.

All Students of GNM final year in selected colleges was taken subsequently by using convenient sampling techniques. Objectives of study were discussed and consent was obtained from participants of the study subjects were assured about the confidentiality of data. On the day 1 , nursing students were instructed to fill the section A selected demographic variables took 10 minutes. Pre -test assessment of knowledge was done on the same day by structured questionnaire. On the same $1^{\text {st }}$ day, after pre-test one booklet each student was provided to them, it took 10 minutes. On the $15^{\text {th }}$ day, $2^{\text {nd }}$ post -test assessment of knowledge of nursing students regarding BMW was done using the same questionnaire and it took around 10 minutes to complete the questionnaire.

\section{Plan for Data Analysis}

- Data were analyzed as follows: Described demographic chacteristics.

- Mean, SD, and mean \% were used to describe area wise knowledge scores.

- Annova and Z' test used to find out association of knowledge with demographic variables

\section{Results}

The demographic characteristics of the respondents revealed that most of the students 95\% belongs to 20-21 years old, about gender $100 \%$ were females, $99 \%$ were residing in hostel and $96 \%$ belongs to Hindu religion .Regarding marital status $99 \%$ of students were unmarried about education $61 \%$ of students completed secondary education and $38 \%$ completed other diploma courses . Around $89 \%$ of student had clinical practice from govt. hospital where as $11 \%$ from private hospital.

Regarding previous knowledge about BMW 90\% revealed that they have knowledge about BMW in which $93 \%$ of students said that the source of information is through books about the location of student college $54 \%$ located in urban and $46 \%$ is rural area.

Table 4.1 Shows Range ,Mean, SD, mean, mean diff., $t$ value comparison of pr- test and post- test score of nursing student

\begin{tabular}{|l|c|c|c|c|c|c|}
\hline "T" Test & Mean \pm S.D. & Mean\% & Range & $\begin{array}{c}\text { Mean } \\
\text { Diff. }\end{array}$ & $\begin{array}{c}\text { "t" } \\
\text { value }\end{array}$ & P value \\
\hline $\begin{array}{l}\text { Pre-test } \\
\text { knowledge }\end{array}$ & $15.16 \pm 3.67$ & 50.50 & $7-22$ & \multirow{2}{*}{9.840} & $\begin{array}{c}21.287 \\
*\end{array}$ & $<0.001 *$ \\
\hline $\begin{array}{l}\text { Post-test } \\
\text { knowledge }\end{array}$ & $25 \pm 3.75$ & 83.30 & $13-30$ & & & \\
\hline
\end{tabular}


Table 4.2 Area wise Mean, Standard deviation, mean percentage, mean difference, "t" value of pre-post knowledge score.

\begin{tabular}{|c|c|c|c|c|c|c|c|c|}
\hline Sr no. & \multicolumn{2}{|l|}{ Area } & Mean & S.D & $\begin{array}{l}\text { Mean } \\
\%\end{array}$ & $\begin{array}{l}\text { Mean } \\
\text { Diff. }\end{array}$ & $\begin{array}{l}\mathrm{t} \\
\text { Valu }\end{array}$ & $P$ value \\
\hline \multirow[t]{2}{*}{1} & \multirow{2}{*}{$\begin{array}{l}\text { (A-miscellaneous } \\
\text { question) }\end{array}$} & Pre & 4.04 & 1.7 & 40.4 & \multirow{2}{*}{3.78} & \multirow{2}{*}{16.4} & \multirow{2}{*}{$<0.001 *$} \\
\hline & & Post & 7.82 & 1.8 & 78.2 & & & \\
\hline \multirow[t]{2}{*}{2} & \multirow{2}{*}{ (B-solids waste) } & Pre & 2.98 & 1.05 & 59.6 & \multirow{2}{*}{1.39} & \multirow{2}{*}{10.8} & \multirow[t]{2}{*}{$<0.001^{*}$} \\
\hline & & Post & 4.37 & 0.82 & 87.4 & & & \\
\hline \multirow[t]{2}{*}{3} & \multirow{2}{*}{ (C-liquid waste) } & Pre & 3.70 & 1.21 & 61.7 & \multirow{2}{*}{0.98} & \multirow{2}{*}{7.7} & \multirow[t]{2}{*}{$<0.001^{*}$} \\
\hline & & Post & 4.68 & 0.60 & 78 & & & \\
\hline \multirow[t]{2}{*}{4} & \multirow{2}{*}{ (D-sharps waste) } & Pre & 2.97 & 1.24 & 42.4 & \multirow{2}{*}{1.34} & \multirow{2}{*}{8.1} & \multirow[t]{2}{*}{$<0.001^{*}$} \\
\hline & & Post & 4.31 & 1.01 & 61.6 & & & \\
\hline \multirow[t]{4}{*}{5} & \multirow{2}{*}{$\begin{array}{l}\text { (E-Laboratory } \\
\text { waste) }\end{array}$} & Pre & 1.47 & 1.07 & 18.4 & \multirow{2}{*}{2.35} & \multirow{2}{*}{13.6} & \multirow[t]{2}{*}{$<0.001 *$} \\
\hline & & Post & 3.82 & 1.67 & 47.8 & & & \\
\hline & \multirow{2}{*}{ Overall knowledge } & Pre & 15.1 & 3.76 & 50.5 & \multirow{2}{*}{9.84} & \multirow{2}{*}{21.2} & \multirow[t]{2}{*}{$<0.001^{*}$} \\
\hline & & Post & 25.0 & 3.6 & 83.3 & & & \\
\hline
\end{tabular}

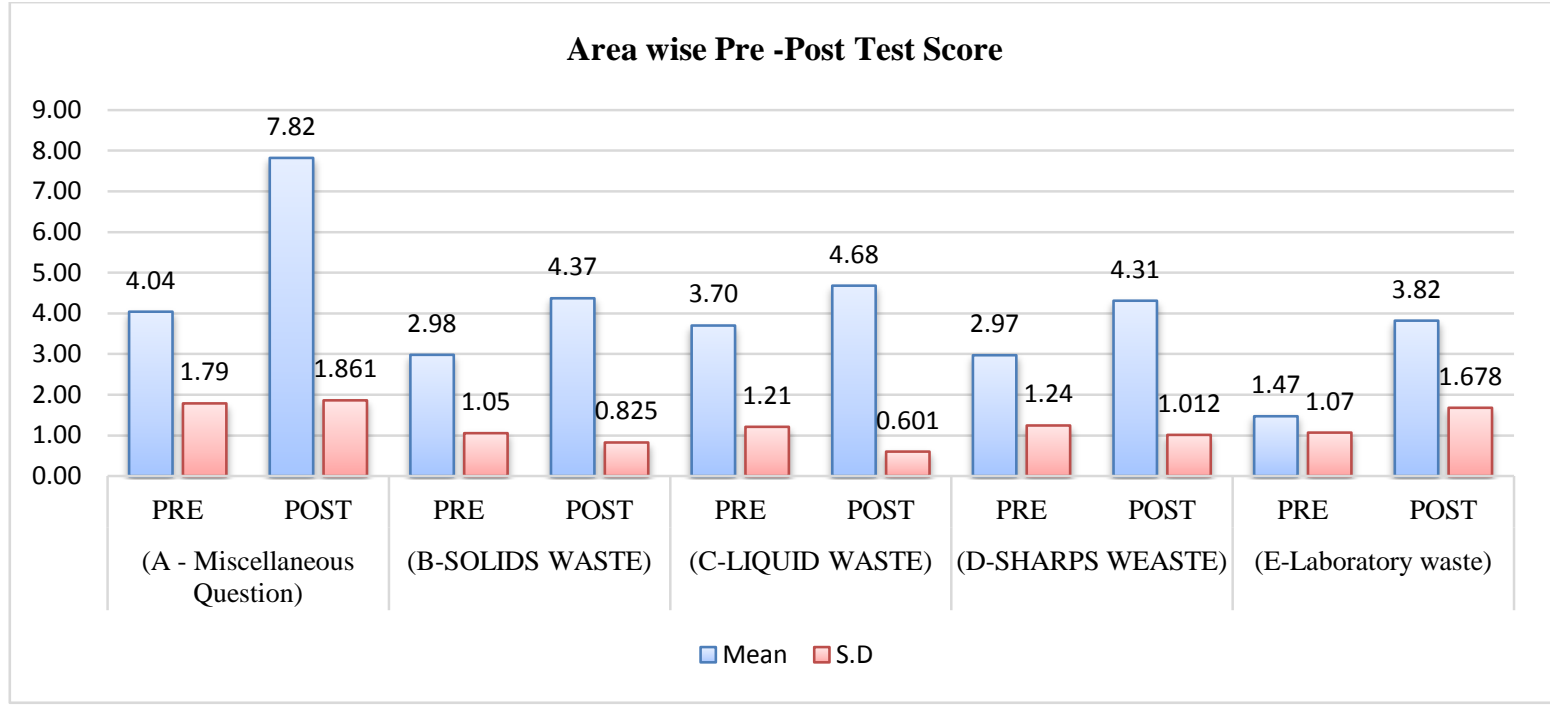

Figure no. 4.1 Bar graph showed score of the nursing students mean and SD value according to the area

\section{Association between knowledge scores and selected demographic variables}

that the association between the level of score and socio demographic variable. Based on the 2nd objectives used to Chi-square test used to associate the level of knowledge and selected demographic variables. The Chi-square value shows that there is significance association between the score level and demographic variables (Religion, In which hospital going to Clinical Practice, Previous Knowledge regarding Bio Medical Waste. Source of Information). There is no significance association between the level of scores and other demographic variables other variables. The calculated chi-square values were less than the table value at the 0.05 level of significance

\section{Recommendations}

1) A replication of the present study can be conducted with large subjects.

2) A study can be done by observing the practice of hospital waste disposal among health care provider

3) A similar study can be conducted in various health care setting. 
4) A comparative study can be done between private and public health care centre.

\section{References}

1. Mrs Anita miller: a study to assess the effectiveness of strudured teaching program on BMW management among staff nurses in selected hospital at Bangulare .

2. Essay on mananagement of BMW in hospital Article shared by NilayMacwan

3. Dr. JayalkshmiL.S VijayammaAjmera, a study to aesses the knowledge regarding BMW management among Bsc Student of selected nursing collage udhaipur vol. 5 ISSUE 4 April 2016.

4. Mansi $S$ center for research in urban affairs Institute for social and economic change Ngarabhoui . P.O Bangalure India.

5. Hppcb.nic .in / BMW 2016 pdf.

6. Shakharkar B.M. Principals of Hospital Administration $1^{\text {st }}$ Ed. New Delhi: Jaypee Publishers 1998.

7. Khairun nessa MA Quaiyeem Barkat-eKhuda Waste management in Health Care Facilities : A Review 2001.

8. Indian Nursing Year Book: Implementation of various technologies for treatment and disposal of Bio-medical waste New Delhi: 2000-2001.

9. Central Pollution Control Board Manual on Hospital Waste Management New Delhi:

10. Ministry of Environment and Forest: 1999.

11. Tanuja shigh, Tika R .Ghimire awareness of bio medical waste management in dental students in different Dental college Nepal 2018.

12. Dhasarathi kumar a study to knowledge level on bio medical waste management among the nurses in Tamilnadu volume 3 2018
13. MrAlin Thomas Cherian effective ness of structured teaching programme on knowledge regarding Bio medical waste management Bombay hospital college of Nursing, Indor , India 2017

14. Amita, Anjana, Ankita Dhiman a study to assess the knowledge and practices regarding bio medical waste management staff nurses at Deen Dayal Upadhyaya Z.H Shimla, (H.P)2017 ;3(8) $704-708$

15. Suganya Panneerselvam knowledge on the Bio medical waste management among Nurses working in Hospital at Madurai 2016 ISSN 2249- 9571

16. Dr Monika Bhardwaj*1 Dr Rajiv Joshi awareness on bio medical waste management among under graduate medical students of Panjab 2016

17. Ananthachari K.P Divya C.V a study to assess the knowledge on bio medical waste management among heath care worker of Malabar Medical College teaching hospital, kerala, India 2016 sep ; 3 (9): 2409- 2413

18. Merlin Mary James ,Macheri Naseem, Chhugani Manju a study to assess the knowledge of Nursing and MBBS Student regarding $\mathrm{BMW}$ management and to, develop an information Booklet on BMW management in a selected university of new Delhi CHN vol/no 22016

19. Shamim Haider, Sneha Kumari a study on knowledge and practice regarding bio medical waste management among staff nurses and nursing student of Rajendra Institute of medical Science, Ranchi India J comm Health. 2015; 27, 1: 135- 138 vol 27 /Issue 01.

20. Ashok kumar Bhardwaj ${ }^{3}$, Abhilash Sood ${ }^{2}$, Mitasha Singh ${ }^{1}$ A study to assess the knowledge about the bio medical waste rules 2011 among the paramedics and laboratory technicians of a tertiary care hospital in north west India " journal of 
evolution of medical and dental sciences 2015; vol. 4Issue 50. /2015/1253.

21. Dr Bhishakhi Paria, Dr Debasis Das, Knowledge and Practice Regarding BMW waste in different levels of Government Health care Facilities in waste Bengal e ISSN; 2279 -0853 p-ISSN 2279 -0861

22. S. Sangeetha Balamurugan Priyadarisini S.P A descriptive study on knowledge Regarding BMW management among health care personnel in a tertiary care Hospital , Salem, Tamil Nadu ,National Journal Research in community Medicine . Vol.3 Issue 22014.

23. Ms .J. Mano Ranjini a study to assess the knowledge BMW disposal among the Group D worker in sri Ramakrishna Hospital , 2014 ; 1(4): 465 -470.

24. Violet N. Pinto, Deepa H. Velanker, Madhavi J. Manker, Acomparative study of knowledge and attiudes regarding BMW management with a preliminary intervention in an cademic hospital .Int $\mathbf{J}$ Med published Health 2014;4:91-5.

25. Nagaraju $B^{1,}$ Padmavathi $G^{2}$, a study to assess the knowledge and practice on bio medical waste management among the health care providers working in PHCs of Bagepalli taluk 2013. 